\title{
Stomatologiczne zachowania prozdrowotne dzieci pięcioletnich - badanie ankietowe rodziców
}

\author{
Dental health-promoting behavior in 5 year-old children \\ - questionnaire study of parents
}

Klinika Stomatologii Dziecięcej Katedry Stomatologii Dziecięcej, Uniwersytet Medyczny im. Karola Marcinkowskiego w Poznaniu

DOI: http://dx.doi.org/10.20883/df.2018.21

\section{STRESZCZENIE}

Wprowadzenie. Nawyki higieniczne propagowane przez rodziców są niezwykle ważnymi czynnikami wpływającymi na zdrowie dzieci. Dlatego też ich okresowa ocena oraz edukacja rodziców, również w odniesieniu do problemów stomatologicznych, stanowi istotny element w kształtowaniu zachowań prozdrowotnych.

Cel. Ocena stomatologicznych zachowań prozdrowotnych dzieci w wieku 5 lat uczęszczających do przedszkoli publicznych i niepublicznych na terenie miasta Poznania w oparciu o badanie ankietowe rodziców.

Materiał i metody. Badanie ankietowe zrealizowane w oparciu o formularz zawierający pytania, jedno- i wielokrotnego wyboru, dotyczące zachowań prozdrowotnych, przeprowadzono u 403 rodziców 5-letnich dzieci przedszkolnych.

Wyniki. W badanej grupie zdecydowana większość (70,97\%) potwierdza dwukrotne w ciągu dnia szczotkowanie zębów przez dzieci, jednak ponad połowa rodziców nie bierze w tej procedurze czynnego udziału (57,82\% opiekunów ogranicza się do wydawania poleceń słownych, a 45,41\% tylko demonstruje metodę szczotkowania). Respondenci podali, iż u 85,61\% dzieci stosowana jest do mycia zębów pasta z zawartością fluoru. Stosunkowo niski odsetek rodziców $(35,24 \%)$ uważa, iż dzieci powinny odbyć pierwszą wizytę u stomatologa w wieku 2 lat, a kolejne wizyty kontrolne co pół roku.

Wnioski. Badania wykazały, iż edukacja opiekunów pięcioletnich dzieci z poznańskich przedszkoli jest konieczna w celu ukształtowania odpowiednich zachowań prozdrowotnych. W procesie tym podkreśla się rolę lekarza stomatologa.

Słowa kluczowe: dzieci przedszkolne, stomatologiczne zachowania prozdrowotne.

\section{ABSTRACT}

Introduction. Hygiene habits promoted by parents are extremely important factors influencing the health of children. Therefore, their periodic assessment as well as parents' education, including dental problems, are significant elements in shaping health-promoting behavior.

Aim. The aim of the study was to evaluate the dental health behavior of children aged 5 years attending public and non-public kindergartens in the city of Poznan, on the basis of a questionnaire survey of their parents.

Material and methods. A questionnaire study was carried out for 403 parents of 5-year-old pre-school children, with the use of a form containing single- and multiple-choice questions concerning health-promoting behavior.

Results. The vast majority $(70.97 \%)$ of the patients confirmed that their children brushed their teeth twice a day. However, more than half of the parents did not participate actively in this procedure $(57.82 \%$ of caregivers give verbal instructions, and $45.41 \%$ only demonstrate the brushing method). The respondents declaired that in $85.61 \%$ of the children toothpaste with fluoride content was used. A relatively low percentage of the parents (35.24\%) considered that children should have their first dental visit at the age of 2 years, and check-up visits every six months.

Conclusions. The research has shown that the education of caregivers of five-year-old children from kindergartens in Poznan is necessary in order to shape appropriate health-promoting behavior. The role of the dentist is emphasized in this process.

Keywords: pre-school children, dental health-promoting behavior. 


\section{Wprowadzenie}

Zachowania dziecka kształtowane są w pierwszej kolejności przez środowisko rodzinne, a potomek nabywa odpowiednie wzorce obserwując rodziców, rodzeństwo czy innych członków rodziny. Także w przypadku sposobów postępowania związanych z higieną jamy ustnej, właściwym żywieniem oraz wykształceniem nawyku poddawania się profesjonalnej kontroli stanu uzębienia postawa rodziców oraz opiekunów ma znaczący wpływ na utrzymanie zdrowia jamy ustnej dzieci. Stąd też przyzwyczajenia ukształtowane w otoczeniu najbliższych są fundamentem poprawnych zachowań także w późniejszych etapach życia dziecka, również po zakończeniu okresu rozwojowego [1, 2]. $\mathrm{U}$ dzieci w wieku przedszkolnym domowe zabiegi higienizacyjne powinny odbywać się przy czynnym udziale osoby dorosłej, polegającym na przestrzeganiu właściwych pór szczotkowania zębów, nauce poprawnego wykonywania tej czynności, a z czasem na jej kontroli. Należy także podkreślić, że zainteresowanie rodziców problemem zdrowia jamy ustnej jest silną motywacją do wdrażania poprawnych zachowań [3-5].

Kolejnym środowiskiem dającym okazję do prowadzenia edukacji prozdrowotnej oraz kształtowania właściwych postaw są przedszkola będące placówkami nauczania i wychowania.

W ramach dbania o zdrowie jamy ustnej dziecka istotną komponentę stanowi zarówno pierwsza wizyta w gabinecie stomatologicznym, jak i kolejne regularne spotkania z lekarzem dentystą w celu kontroli stanu uzębienia oraz realizacji zabiegów profilaktycznych i leczniczych. Jest ona także okazją do edukacji rodziców w zakresie odpowiednich zachowań prozdrowotnych [6-8]. Niezmiernie ważne wydaje się również określenie ryzyka zachorowania na próchnicę, co jest szczególnie istotne w zapobieganiu i ograniczaniu zaawansowania tej choroby w wieku rozwojowym [9].

\section{Cel}

Celem pracy było zebranie danych dotyczących stomatologicznych zachowań prozdrowotnych dzieci 5-letnich uczęszczających do przedszkoli na terenie miasta Poznania w oparciu o badanie ankietowe rodziców.

\section{Materiał i metody}

Badania wykonano w ramach Projektu „Edukacja, promocja i profilaktyka w kierunku zdrowia jamy ustnej skierowana do małych dzieci, ich rodziców, opiekunów i wychowawców" współrealizowanego przez Szwajcarię w ramach szwajcarskiego pro- gramu współpracy z nowymi krajami członkowskimi Unii Europejskiej oraz ze środków Ministerstwa Zdrowia (KIK 33) [10]. Analizę przeprowadzono $z$ wykorzystaniem danych zebranych $w$ kwestionariuszu ankiety, zawierającym pytania jednoi wielokrotnego wyboru, w grupie 403 osób. Były to wypowiedzi jednego z rodziców dzieci uczęszczających do przedszkoli publicznych i niepublicznych na terenie miasta Poznania w roku szkolnym 2015/2016.

Pytania zawarte $w$ formularzu dotyczyły zachowań prozdrowotnych i odnosiły się do częstości szczotkowania zębów przez dzieci i sposobów pomocy w jego przeprowadzaniu udzielanej przez rodziców i opiekunów oraz stosowania past z fluorem. Rodzice poproszeni zostali także o zaznaczenie prawidłowych stwierdzeń dotyczących częstości kontroli stomatologicznych uzębienia dzieci oraz zwyczajów żywieniowych. Badane osoby na pytania odpowiadały samodzielnie.

Analizę statystyczną uzyskanych danych w badanych grupach przeprowadzono testem różnic między dwoma wskaźnikami struktury przy użyciu programu Statistica v. 10. Oceniono istotność statystyczną różnic pomiędzy odpowiedziami rodziców dziewczynek i chłopców oraz rodziców dzieci uczęszczających do przedszkoli publicznych i niepublicznych. Za istotne uznano różnice, przy których poziom istotności był niższy od 0,05 ( $p<0,05)$. Obliczeń statystycznych dokonano w Zakładzie Bioinformatyki i Biologii Obliczeniowej Katedry Patomorfologii Klinicznej Uniwersytetu Medycznego im. Karola Marcinkowskiego w Poznaniu.

Przed przystąpieniem do badań uzyskano zgodę Komisji Bioetycznej przy Uniwersytecie Medycznym im. Karola Marcinkowskiego w Poznaniu (uchwała nr 784/15), oraz zgodę dyrektorów placówek, a także rodziców i opiekunów dzieci.

\section{Wyniki}

Zdecydowana większość rodziców (70,97\%) uczestniczących w badaniach zadeklarowała, że ich dzieci szczotkują zęby dwukrotnie w ciągu dnia. Natomiast jeden raz dziennie zabiegi higieniczne w jamie ustnej wykonuje 17,12\% przedszkolaków (Tabela 1). Wśród pięciolatków uczęszczających do przedszkoli publicznych postępuje $w$ ten sposób $19,88 \%$ w porównaniu do $5,26 \%$ dzieci z przedszkoli niepublicznych (Tabela 1). Natomiast częściej niż dwukrotnie w ciągu dnia oczyszcza zęby $11,17 \%$ pięciolatków, przy czym takie zachowanie potwierdza $22,37 \%$ rodziców dzieci z przedszkoli niepublicznych oraz $8,56 \%$ rodziców dzieci uczęszczających do przedszkoli publicznych. Uzyskane 
Tabela 1. Odpowiedzi rodziców na pytania dotyczące częstości oczyszczania zębów dziecka, pomocy rodziców przy zabiegu oraz pierwszej wizyty u stomatologa, konieczności leczenia zębów mlecznych i szkodliwości podjadania pomiędzy posiłkami

Table 1. Answers of parents to the questioons concerning frequency of teets cleaning, assistance of parents with this procedure, first visit of the child at the dental surgery, need for treatment of deciduous teeth and harmfulness of snacking between meals

\begin{tabular}{|c|c|c|c|c|c|c|c|c|}
\hline \multirow[t]{2}{*}{ Pytanie } & \multirow[t]{2}{*}{ Odpowiedzi } & 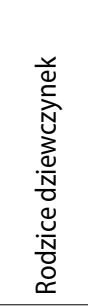 & 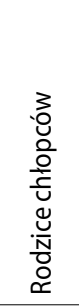 & 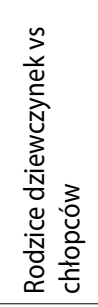 & 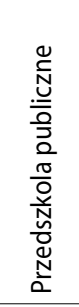 & 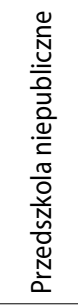 & 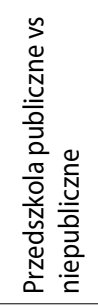 & $\frac{\frac{\varepsilon}{d}}{\frac{0}{0}}$ \\
\hline & & $\%$ & $\%$ & $\mathrm{p}$ & $\%$ & $\%$ & $\mathrm{p}$ & $\%$ \\
\hline \multirow{5}{*}{$\begin{array}{l}\text { Jak często } \\
\text { dziecko czyści } \\
\text { zęby? }\end{array}$} & Sporadycznie & 0,50 & 0,49 & ns & 0,61 & 0,00 & ns & 0,50 \\
\hline & Raz dziennie & 18,00 & 16,26 & ns & 19,88 & 5,26 & 0,002 & 17,12 \\
\hline & Dwa razy dziennie & 70,50 & 71,43 & ns & 70,64 & 72,37 & ns & 70,97 \\
\hline & Częściej niż dwa razy dziennie & 11,00 & 11,33 & ns & 8,56 & 22,37 & $<0,001$ & 11,17 \\
\hline & Brak odpowiedzi & 0,00 & 0,49 & ns & 0,31 & 0,00 & ns & 0,25 \\
\hline \multirow{5}{*}{$\begin{array}{l}\text { W jaki sposób } \\
\text { Pani/Pan } \\
\text { pomaga } \\
\text { dziecku przy } \\
\text { czyszczeniu } \\
\text { zębów? }\end{array}$} & Polecenie słowne & 56,00 & 59,61 & ns & 56,27 & 64,47 & ns & 57,82 \\
\hline & Demonstracja sposobu szczotkowania & 50,50 & 40,39 & 0,04 & 45,87 & 43,42 & ns & 45,41 \\
\hline & Trzymanie szczotki i kierowanie jej ruchem & 42,00 & 43,35 & ns & 42,81 & 42,11 & ns & 42,68 \\
\hline & Nie pomagam & 8,00 & 5,91 & ns & 7,65 & 3,95 & ns & 6,95 \\
\hline & Brak odpowiedzi & 0,50 & 0,49 & ns & 0,00 & 2,63 & ns & 0,50 \\
\hline \multirow{7}{*}{$\begin{array}{l}\text { Zaznacz } \\
\text { prawidłowe } \\
\text { stwierdzenia: }\end{array}$} & $\begin{array}{l}\text { Dzieci powinny odbyć pierwszą wizytę u dentysty w wieku } 12 \\
\text { miesięcy }\end{array}$ & 30,00 & 38,42 & ns & 34,56 & 32,89 & ns & 34,24 \\
\hline & Dzieci powinny odbyć pierwszą wizytę u dentysty w wieku 2 lat & 43,00 & 27,59 & $<0,001$ & 35,47 & 34,21 & ns & 35,24 \\
\hline & Dzieci powinny odbyć pierwszą wizytę u dentysty w wieku 3 lat & 16,50 & 20,20 & ns & 17,13 & 23,68 & ns & 18,36 \\
\hline & $\begin{array}{l}\text { Zęby mleczne nie wymagają takiej troski jak stałe, ponieważ } \\
\text { wypadną }\end{array}$ & 1,00 & 2,46 & ns & 1,83 & 1,32 & ns & 1,74 \\
\hline & Próchnica zębów mlecznych „przenosi” się na zęby stałe & 65,00 & 60,10 & ns & 64,53 & 53,95 & ns & 62,53 \\
\hline & $\begin{array}{l}\text { Częste pojadanie między posiłkami przyczynia się do rozwoju } \\
\text { próchnicy }\end{array}$ & 64,00 & 62,07 & ns & 65,75 & 51,32 & 0,02 & 63,03 \\
\hline & Brak odpowiedzi & 3,50 & 4,43 & ns & 4,5 & 3,45 & ns & 3,97 \\
\hline
\end{tabular}

wyniki wskazują na bardziej poprawne realizowanie zachowań prozdrowotnych w odniesieniu do częstości wykonywania zabiegów higienicznych w jamie ustnej przez dzieci uczęszczające do przedszkoli niepublicznych, co zostało potwierdzone statystycznie (Tabela 1). Analiza danych przeprowadzona w odniesieniu do płci nie wykazała istotnych statystycznie różnic.

Jak wynika z odpowiedzi rodziców najczęstszą formą pomocy podczas procedury szczotkowania zębów przez dzieci jest wydawanie poleceń słownych $(57,82 \%)$. Natomiast $6,95 \%$ respondentów przyznało, iż nie wspiera dziecka w wykonywaniu zabiegów higienicznych w obrębie jamy ustnej (Tabela 1). Ponadto znaczna liczba rodziców $(45,41 \%)$ potwierdziła, że demonstruje metodę oczyszczania zębów (50,50\% rodziców dziewczynek w porównaniu do 40,39\% rodziców chłopców), przy czym dziewczynki są statystycznie istotnie częściej edukowane przez rodziców w tym zakresie (Tabela 1).

Odpowiedzi uzyskane na pytanie dotyczące używanych preparatów wykazały, że większość pięciolatków myje zęby pastą z fluorem $(85,61 \%)$, natomiast $9,68 \%$ rodziców wybiera dla swoich dzieci środki nie zawierające tego pierwiastka (Rycina 1).

W kolejnym pytaniu ankiety dotyczącym opieki stomatologicznej poproszono rodziców dzieci o zaznaczenie wybranych przez nich stwierdzeń prawidłowych. Większość respondentów uważała, że pierwszą wizytę w gabinecie stomatologicznym dziecko powinno odbyć w pierwszych dwóch latach życia (od 34,24\% do 35,24\%) (Tabela 1). Dalsza analiza uzyskanych wyników wykazała, że 30,00\% rodziców dziewczynek i 38,42\% chłopców uważa, że pierwsza wizyta dziecka u lekarza stomatologa powinna mieć miejsce w pierwszym roku ży- 
cia, natomiast odpowiednio 43,00\% i 27,59\% sądzi, że taką wizytę należy odbyć w wieku 2 lat. Wskazuje to na większą świadomość w odniesieniu do realizacji pierwszej wizyty dziecka u stomatologa rodziców chłopców. Natomiast analizując odpowiedzi rodziców pięciolatków zależnie od rodzaju przedszkola, stwierdzono zbliżoną wiedzę na ten temat obu grup. Świadomość respondentów odnośnie konieczności odbycia pierwszej wizyty dziecka u dentysty w pierwszym lub drugim roku życia kształtowała się odpowiednio 34,56\% i $32,89 \%$ oraz $35,47 \%$ i 34,21\%. Ankietowani rodzice mieli również świadomość konieczności dbania o zęby mleczne, co potwierdziło $62,53 \%$ badanych. Znaczna liczba respondentów $(63,03 \%)$ posiadała także wiedzę o szkodliwości podjadania pomiędzy posiłkami. W tej grupie znalazło się $65,75 \%$ rodziców dzieci uczęszczających do przedszkoli publicznych w porównaniu do 51,32\% rodziców pięciolatków z przedszkoli niepublicznych. Różnice te zostały potwierdzone statystycznie $(p=0,02)$ (Tabela 1).
Sprawdzając wiedzę rodziców dotyczącą lekarskich kontroli stomatologicznych odnotowano, iż większość z nich uważa, że dzieci powinny zgłaszać się do dentysty co pół roku $(69,48 \%)$ (Rycina 2). Zdaniem 18,61\% ankietowanych opiekunów takie wizyty powinny odbywać się raz w roku, a 2,98\% respondentów uważa, że zgłaszać się do dentysty należy dopiero w przypadku pojawienia się dolegliwości bólowych zębów. Blisko 12\% ankietowanych rodziców nie udzieliło odpowiedzi na to pytanie (Rycina 2).

\section{Dyskusja}

Stan zdrowia jamy ustnej dzieci zależy w dużym stopniu od wiedzy i realizacji zachowań prozdrowotnych ich rodziców, gdyż nawyki higieniczne oraz dietetyczne wprowadzane i utrwalane są w okresie niemowlęcym i wczesnego dzieciństwa. Przekształcenie zasobów wiedzy w nawyk jest procesem długoletnim i wymaga wprowadzenia kolejnych etapów postępowania, takich jak świadomość własnych potrzeb zdrowotnych, zaintere-

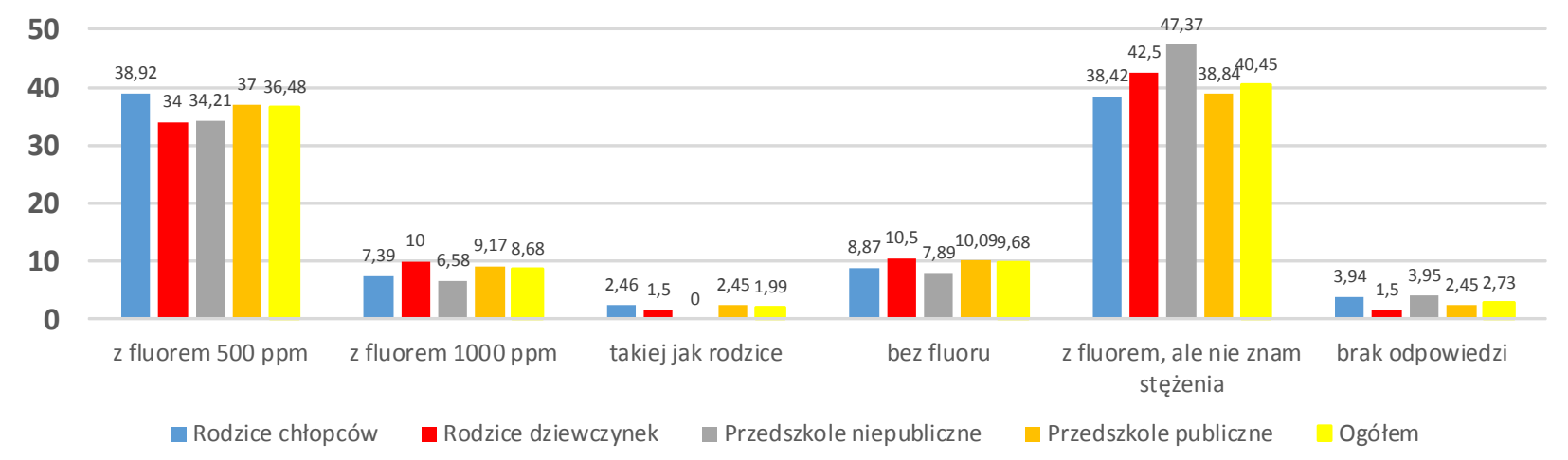

Rycina 1. Odpowiedzi rodziców na pytanie: Jakiego rodzaju pasty używa obecnie dziecko do czyszczenia zębów? (\%) Figure 1. Answers of parents to the question: What kind of toothpaste is currently used by yout child? (\%)

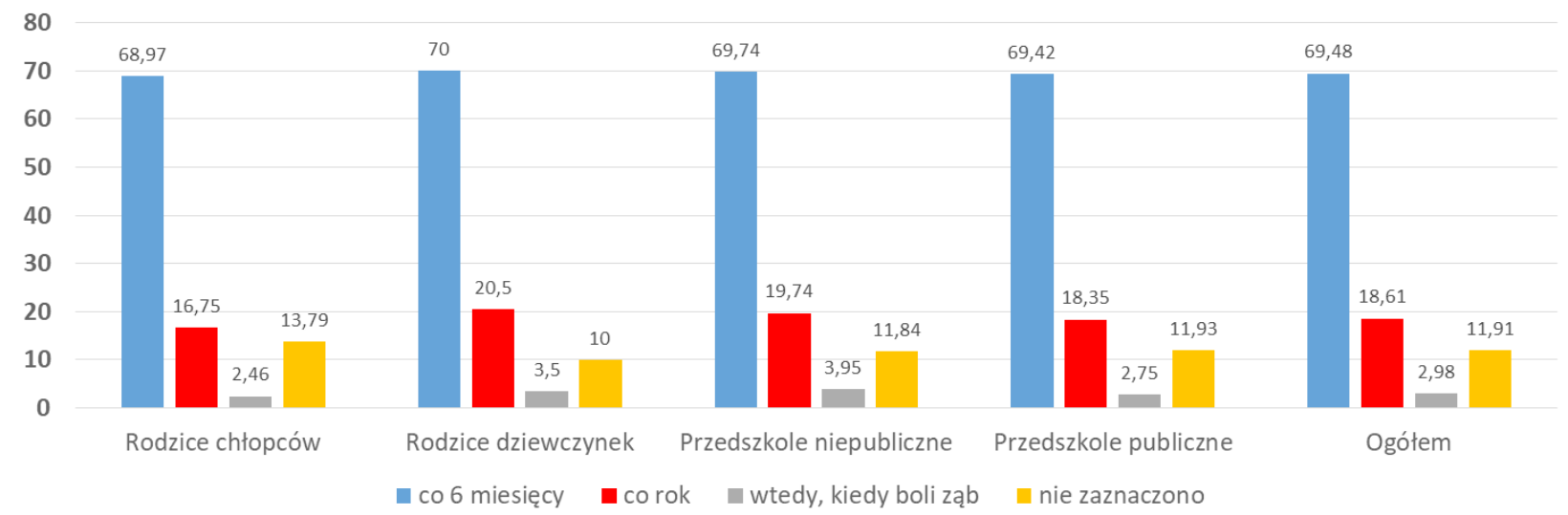

Rycina 2. Odpowiedzi na pytanie: Jak często dzieci powinny zgłaszać się do kontroli stomatologicznej? (\%)

Figure 2. Answers to the question: How often should children dental examination be carried out? (\%) 
sowanie, zaangażowanie i działanie w celu utrzymania zdrowia jamy ustnej [11-13].

Jednym z działań zapobiegawczych jest nawyk systematycznego oczyszczania zębów. Zaprezentowane wyniki badania ankietowego rodziców wskazują, że zdecydowana większość pięciolatków przeprowadza podstawowe zabiegi higieniczne w obrębie jamy ustnej z prawidłową częstością. Znajduje to potwierdzenie w danych uzyskanych przez innych badaczy prowadzących obserwacje w populacji dzieci $[3,5,14-17]$.

U małego dziecka czynna pomoc osoby dorosłej w oczyszczaniu zębów jest niezbędnym elementem dbania o higienę jamy ustnej. Uznaje się, że zanim osiągnie ono wiek szkolny pomoc ta warunkuje uzyskanie zadowalającego efektu. Badania własne wykazały, iż u ponad połowy pięciolatków $(57,82 \%)$ pomoc rodziców podczas procedury szczotkowania zębów polega jedynie na wydawaniu poleceń słownych. Wynik ten jest zbliżony do uzyskanego przez Huebner i Riedy w tej samej grupie wiekowej (55\%) [18]. Podobne wyniki $(43,2 \%)$ uzyskały także Małkiewicz i wsp. prowadząc badania w grupie 155 opiekunów dzieci 3-letnich [17]. Ponadto dodać trzeba, że znaczny odsetek ankietowanych opiekunów (45,41\%) demonstruje swoim dzieciom technikę wykonywania zabiegów higienicznych w jamie ustnej, po czym dziecko samodzielnie szczotkuje zęby. Powyższe dane świadczyć mogą o tym, że rodzice nie rozumieją ograniczeń wynikających z faktu, że skuteczne szczotkowanie zębów wymaga dojrzałości motorycznej oraz odpowiedniego poziomu rozwoju intelektualnego. Zdolność wynikająca z poziomu rozwoju warunkująca skuteczność oczyszczania zębów z płytki nazębnej jest nabywana u dzieci po 7 roku życia, a wcześniej potrzebna jest do realizacji tego celu pomoc ze strony opiekunów [4, 19].

Wysoki odsetek pięciolatków uczęszczających do poznańskich przedszkoli $(85,61 \%)$ stosuje pasty do zębów z zawartością związków fluoru, co jest zgodne z obecnymi zaleceniami profilaktyki przeciwpróchnicowej [1]. Zastanawia jednak fakt, iż znaczna grupa rodziców (40,45\%) nie zwraca uwagi na stężenie fluoru w wybieranej dla dziecka paście, a blisko 10\% preferuje pastę bezfluorową. Stąd też wyniki wskazują na potrzebę podnoszenia poziomu wiedzy prozdrowotnej opiekunów dzieci w wieku przedszkolnym, gdyż wydaje się, iż ani nie znają oni aktualnych zaleceń ani nie rozumieją działania profilaktycznego pasty.

Niezaprzeczalnym warunkiem zachowania zdrowia jamy ustnej są regularne wizyty u stomatologa. Przyczyniają się one do poprawy zachowań w zakresie higieny i diety oraz kontroli rozwoju ogólnego dziecka i stanu tkanek jamy ustnej $[9,20]$. Jak wynika z badań własnych stosunkowo niewielki odsetek badanych rodziców uważa, iż pierwsza wizyta dziecka w gabinecie stomatologicznym powinna odbyć się w pierwszych dwóch latach życia. Tymczasem zaleca się, aby pierwsza wizyta w gabinecie stomatologicznym miała miejsce w okresie 6 miesięcy od wyrznięcia pierwszego zęba mlecznego, nie później jednak niż do ukończenia przez dziecko pierwszego roku życia [3].

Brak systematycznej opieki stomatologa może wpływać na pogorszenie się stanu zdrowia jamy ustnej zarówno u dzieci, jak i u osób dorosłych. W obecnych badaniach wprawdzie większość rodziców $(69,48 \%)$ ma świadomość konieczności odbywania regularnych wizyt z dzieckiem u stomatologa w celu kontroli stanu uzębienia co 6 miesięcy, jednak blisko $12 \%$ respondentów nie udzieliło odpowiedzi na to pytanie, a 2,98\% uważa, że zgłaszać się do lekarza dentysty należy w przypadku wystąpienia dolegliwości bólowych. Na takie postępowanie zwracają również uwagę inni autorzy prowadzący badania wśród młodzieży, dla której pojawienie się bólu jest jednym z głównych powodów wizyty u stomatologa [21, 22]. Może to zatem wskazywać na powielanie niekorzystnych zachowań nabytych w dzieciństwie [21]. Dlatego też, bardzo duże znaczenie mają działania służące podnoszeniu świadomości zarówno dzieci, jak i rodziców, co do konieczności zgłaszania się na badania kontrolne do stomatologa pomimo braku jakichkolwiek niepokojących objawów. Podkreślić też należy, że zgodnie ze stanowiskiem Amerykańskiej Akademii Stomatologii Dziecięcej (American Academy of Pediatric Dentistry - AAPD) tylko regularne wizyty umożliwiają odpowiednie prowadzenie edukacji prozdrowotnej w zakresie nawyków żywieniowych i domowej profilaktyki przeciwpróchnicowej oraz profesjonalną aplikację środków fluorkowych i lakowanie świeżo wyrzniętych zębów trzonowych u pacjentów z podwyższonym ryzykiem próchnicy [17].

W badaniach własnych ponad połowa rodziców dzieci 5-letnich ma świadomość, iż obecność ubytków próchnicowych w obrębie uzębienia mlecznego ma niekorzystny wpływ na stan zdrowia zębów stałych. Niewielka liczba respondentów twierdziła, iż leczenie zębów mlecznych jest bezcelowe ze względu na ich późniejszą fizjologiczną utratę. Wielu autorów zwraca uwagę na fakt, że ogólny stan zdrowia jest powiązany ze stanem zdrowia jamy ustnej, dlatego też choroby jamy ustnej muszą być brane pod uwagę w aspekcie moż- 
liwości rozwoju i trudności leczenia niektórych już istniejących chorób ogólnych dziecka [11, 12, 17, 23, 24]. Stąd też otrzymane wyniki mogą sugerować, iż część badanych opiekunów nie docenia, bądź nie ma świadomości, jak ważna jest rola lekarza dentysty w prawidłowym rozwoju i utrzymaniu zdrowia dziecka.

\section{Wnioski}

Przeprowadzone badania wskazują na niezadowalające stomatologiczne zachowania prozdrowotne dzieci 5-letnich, a co za tym idzie, na potrzebę edukacji rodziców dzieci w wieku przedszkolnym w zakresie dbania o zdrowie jamy ustnej. Może to wynikać z niedostatecznego poziomu wiedzy w tym zakresie lub też z niedoceniania tego problemu zdrowotnego. Niezwykle istotna wydaje się zatem rola lekarza stomatologa, który podczas pierwszej wizyty dziecka lub kobiety spodziewającej się potomstwa, powinien udzielić wskazań żywieniowych i higienicznych, a podczas kolejnych kontrolować prawidłowość zachowań zdrowotnych. Informacje takie powinny być jednym z elementów podstawowej edukacji zdrowotnej.

\section{Oświadczenia}

Oświadczenie dotyczące konfliktu interesów

Autorzy deklarują brak konfliktu interesów w autorstwie oraz publikacji pracy.

\section{Źródła finansowania}

Autorzy deklarują brak źródeł finansowania.

\section{Piśmiennictwo}

[1] Olczak-Kowalczyk D, Borysewicz-Lewicka M, Adamowicz-Klepalska B, Jackowska T, Kaczmarek U. Stanowisko polskich Ekspertów dotyczące indywidulanej profilaktyki fluorkowej choroby próchnicowej u dzieci i młodzieży. Nowa Stomatol. 2016;21(1):47-73.

[2] Szatko F, Wierzbicka M, Dybiżbańska E, Strużycka I, Iwanicka-Frankowska E. Oral health of Polish three-year-olds and mothers' oral health related knowledge. Community Dental Health. 2004;21(2):175-180.

[3] Bruzda-Zwiech A, Filipińska R, Szydłowska-WalendowskaB,Lubowiedzka-GontarekB, Wochna-Sobańska M. Stomatologiczne zachowania prozdrowotne 4-5-letnich dzieci w świetle badań ankietowych rodziców. Dent Med Probl. 2012;49(2):272-278.

[4] BSPD and IADPD: British Society of Paediatric Dentistry. A policy document on oral health care in preschool children. Int J Pediatr Dent. 2003;13(4):279285.

[5] Królewska-Gawarzyńska J. Stomatologiczne zachowania prozdrowotne a stan uzębienia łódzkiej młodzieży 18-letniej. Nowa Stomatol. 2015;20(4):153-158.

[6] Szczepańska J, Szydłowska B, Lubowiedzka B, Pawłowska E. Analysis of risk factors for caries in 3-year old children. Czas Stomatol. 2007;60(3):162-170.
[7] Wierzbicka M, Szatko F, Pierzynowska E, Zawadziński M, Dybiżbańska E, Małkiewicz E, Ganowicz M, Strużycka I, Iwanicka-Frankowska E. Świadomość i zachowania zdrowotne matek małych dzieci w Polsce z początkiem nowego tysiąclecia. Stomatol Współcz. 2003;10(4):8-12.

[8] Bedi R, Lewsey JD, Gilthorpe MS. Changes in oral health over ten years amongst UK children aged 4-5 years living in a deprived multiethnic area. Br Dent J. 2000;189(2):88-92.

[9] Williams NJ, Whittle JG, Gatrell AC. The relationship between socio-demographic characteristics and dental health knowledge and attitudes of parents with young children. Br Dent J. 2002;193(11):651-654.

[10] Borysewicz-Lewicka M, Gerreth K, Gmerek P. Promowanie zdrowia jamy ustnej dzieci przedszkolnych materiały edukacyjne. Dent Forum. 2015,43(2):99102.

[11] Grzesiak-Gasek I, Kaczmarek U. Wiedza rodziców na temat zdrowia jamy ustnej w odniesieniu do intensywności próchnicy u ich dzieci w wieku 6-7 lat. Dent Med Probl. 2015;52(2):184-191.

[12] Fisher-Owens SA, Barker JC, Adams S, Chung LH, Gansky SA, Hyde S, Weintraub JA.. Giving policy some teeth: routes to reducing disparities in oral health. Health Aff. 2008;27(2):404-412.

[13] Sheiham A, Watt RG. The common risk factor approach: a rational basis for promoting oral health. Community Dent Oral Epidemiol. 2000;28(6):399-406.

[14] Grzesiak I, Kaczmarek U. Pierwsza wizyta dziecka w gabinecie stomatologicznym. Dent Med Probl. 2006;43(3):433-437.

[15] Wiener RC, Crout RJ, Wiener MA. Toothpaste use by children, oral hygiene and nutritional education: an assessment of parental performance. J Dent Hyg. 2009;83(3): 141-145.

[16] Daszkowska M, Lubowiedzka B, Szydłowska B, Wochna-Sobańska M. Ocena nawyków higienicznych i żywieniowych dzieci przedszkolnych objętych programem profilaktyki próchnicy. Dent Med Probl. 2003;40(2):305-308.

[17] Małkiewicz E, Borkowska T, Wierzbicka M. Świadomość stomatologiczna i zachowania zdrowotne opiekunów dzieci zainteresowanych programami profilaktycznymi. Probl Hig Epidemiol. 2012;93(1):90-96.

[18] Huebner CE, Riedy CA. Behavioral determinants of brushing young children's teeth: implications for anticipatory guidance. Pediatr Dent. 2010;32(1):48-55.

[19] White DA, Chadwick BL, Nuttall NM, Chestnutt IG, Steele JG. Oral health habits amongst children in the United Kingdom in. 2003. Br Dent J. 2006;200(9):487491.

[20] Vallejos-Sanchez AA, Medina-Solis CE, Maupome G, Casanova-Rosado JF, Minaya-Sánchez M, Villalobos-Rodelo JJ, Pontigo-Loyola AP. Sociobehavioral factors influencing toothbrushing frequency among schoolchildren. J Am Dent Assoc. 2008,139(6):743749.

[21] Astrom AN, Jakobsen R. The effect of parental dental health behavior on that of their adolescent offspring. Acta Odontol Scand. 1996;54(4):235-241. 
[22] Królewska-Gawarzyńska J, Proc P, Daszkowska M, Wochna-Sobańska M. Nawyki żywieniowe łódzkiej młodzieży licealnej w świetle badań ankietowych. Dent Med. Probl. 2014,51(1):86-92.

[23] Kolarzyk E, Janik A, Kwiatkowski J. Zwyczaje żywieniowe dzieci w wieku przedszkolnym. Prob Hig Epidemiol. 2008,89(4):527-532.

[24] Jarząbek A, Lisiecka K, Wieczkowska I, Węsierska K. Wpływ 2-letniego programu profilaktyki próchnicy na stan zdrowia jamy ustnej 3-letnich dzieci. Dent Med Probl. 2012;49(2):230-236.

Zaakceptowano do edycji: 2018-10-16 Zaakceptowano do publikacji: 2018-12-05

\section{Adres do korespondencji:}

Renata Śniatała

Klinika Stomatologii Dziecięcej

Katedra Stomatologii Dziecięcej

Uniwersytet Medyczny im. Karola Marcinkowskiego w Poznaniu

ul. Bukowska 70, 60-812 Poznań

tel.: 618547053

fax.: 618547059

e-mail: klstomdz@ump.edu.pl 